\title{
PENGARUH EDUKASI STUNTING MENGGUNAKAN METODE AUDIOVISUAL DAN BOOKLET TERHADAP PENGETAHUAN IBU DENGAN ANAK STUNTING
}

\author{
Ajeng Maharani Pratiwi ${ }^{1)}$,Erinda Nur Pratiwi ${ }^{2)}$. \\ ${ }^{1}$ Universitas Kusuma Husada Surakarta \\ ${ }^{2}$ Universitas Kusuma Husada Surakarta \\ Email:ajengpratiwi937@gmail.com
}

\begin{abstract}
ABSTRAK
Latar Belakang: Stunting merupakan kondisi gagal tumbuh untuk mencapai pertumbuhan normal yang diakibatkan oleh status gizi kurang dalam periode waktu lama. Pencegahan serta penanganan stunting dapat dilakukan dengan meningkatkan pengetahuan ibu yang memiliki anak stunting agar tidak berlanjut pada anak selanjutnya. Pemberian edukasi pada ibu dapat dilakukan menggunakan metode audiovisual dan booklet. Tujuan Penelitian: mengetahui pengaruh pemberian edukasi dengan metode audiovisual dan booklet terhadap pengetahuan ibu tentang stunting di Desa Jekani Kecamatan Mondokan Sragen. Metode Penelitian: Penelitian ini adalah penelitian kuantitatif dengan menggunakan non equivalent control group design yang dilaksanakan pada bulan september 2020. Sampel penelitian ini adalah 60 orang ibu - ibu dengan anak stunting. Analisis data menggunakan Paired t-test, Independent t-test, dan Chi Square. Alat ukur yang digunakan adalah kuesioner. Hasil Penelitian: Terdapat peningkatan pengetahuan antara dua kelompok dengan $p$-value $=0.000$. Kesimpulan: Terdapat perbedaan pengaruh edukasi terhadap pengetahuan ibu dengan anak stunting dengan metode audiovisual dan booklet.
\end{abstract}

Kata Kunci: audiovisual, booklet, pengetahuan ibu, stunting

\section{ABSTRACT}

Background: Stunting is a condition of failure to thrive in achieving healthy growth due to poor nutritional status for a sustained period. Stunting prevention and management could be performed by increasing the mother's knowledge of stunted children. Therefore, it does not continue to the next child. Education for mothers could be applied using audiovisual methods and booklets. Objective: The study aimed determine the effect of education with audiovisual methods and booklets on mother's knowledge about stunting in Jekani Village, Mondokan District of Sragen. Method: It adopted a quantitative study with a non-equivalent control group design in September 2020. The sample was 60 mothers with stunting children. The data analysis applied Paired t-test, an Independent t-test, and Chi-Square with a questionnaire measuring instrument. Result: There was a knowledge improvement between the two groups with a p-value $=0.000$. Conclusion: There is a different effect of education on the mother's knowledge with stunting children using audiovisual methods and booklets.

Keywords: Audiovisual, Booklet, Mother's Knowledge, Stunting.

\section{PENDAHULUAN}

Stunting merupakan ancaman utama terhadap kualitas manusia, juga ancaman terhadap kemampuan daya saing bangsa (Kemenkes, 2018). Masalah stunting merupakan salah satu permasalahan yang dihadapi di dunia khususnya di negara-negara miskin dan berkembang (Unicef, 2013). Data WHO (2017) mencatat lebih dari setengah balita stunting di dunia berasal dari Asia (55\%) sedangkan lebih dari sepertiga (39\%) tinggi di Afrika. Dari 83,6 juta balita stunting di Asia, proporsi terbanyak berasal dari Asia Selatan $(58,7 \%)$ dan proporsi paling sedikit di Asia Tengah (0,9\%). (Unicef, 2013). Stunting merupakan prediktor buruknya kualitas sumber daya manusia yang selanjutnya akan berpengaruh pada pengembangan potensi bangsa (Unicef, 2013; UNICEF Indonesia, 2013). Berdasarkan data Riskesdas (2017) prevalensi anak balita stunting di Indonesia mengalami peningkatan pada tahun 2016 sebesar 27,5\% menjadi 29,6\% pada tahun 2017. Menurut Riskesdas (2018) prevalensi stunting 
di Jawa Tengah 33,4\% sedangkan di Kabupaten Sragen prevalensinya $39,7 \%$ berarti saat ini prevalensi stunting di Kabupaten Sragen lebih tinggi dibandingkan dengan angka nasional maupun Jawa Tengah. Menurut data Dinas Kesehatan Kabupaten Sragen tahun 2019 angka kejadian stunting yang tertinggi berada di Kecamatan Mondokan sebesar 24,2 \% (Pemerintah Kabupaten Sragen, 2019).

Alat bantu yang digunakan pada metode booklet adalah buku, sedangkan pada metode audiovisual menggunakan video mengenai penyebab dan cara pencegahan stunting. Metode-metode tersebut mengharuskan semua ibu terlibat aktif untuk menyatakan pendapat dan pengalamannya mengenai stunting.

Audio visual adalah media instruksional modern yang sesuai dengan perkembangan zaman (kemajuan ilmu pengetahuan dan tekhnologi), meliputi media yang dapat dilihat dan di dengar (Rohani, 2015). Media audio visual yaitu media yang merupakan kombinasi audio dan visual atau disebut dengan media pandang-dengar. Contoh dari media audio visual adalah program video/televisi pendidikan, video intruksional, dan program slide suara (sound slide) (Rusman, 2017).

Booklet termasuk salah satu jenis media grafis yaitu media gambar/foto. Menurut Roymond S. Simamora (2016), Booklet adalah buku berukuran kecil (setengah kuarto) dan tipis, tidak lebih dari 30 lembar bolak balik yang berisi tentang tulisan dan gambar- gambar. Istilah booklet berasal dari buku dan leaflet artinya media booklet merupakan perpaduan antara leaflet dan buku dengan format (ukuran) yang kecil seperti leaflet. Struktur isi booklet menyerupai buku (pendahuluan,isi,penutup), hanya saja cara penyajian isinya jauh lebih singkat dari pada buku. Berdasarkan hasil studi pendahuluan dengan menyebar kuesioner yang telah dilakukan pada 6 ibu yang memiliki anak stunting di Desa Jekani didapatkan $4(66,6 \%)$ orang yang memiliki pengetahuan yang kurang

\section{HASIL

\section{Uji Normalitas}

Tabel 1

Uji Normalitas pada Kelompok Eksperimen ${ }^{1}$ dan Kelompok Eksperimen ${ }^{2}$

\begin{tabular}{cccc}
\hline Kelompok & $\mathrm{N}$ & Asymp. Sig Pretest & Asymp.Sig Posttest \\
\hline Audiovisual & 30 & 0,434 & 0,561 \\
Media Booklet & 30 & 0,221 & 0,565 \\
\hline
\end{tabular}

tentang stunting dan $2(33,4 \%)$ orang yang memiliki pengetahuan baik tentang stunting. Dari penelitian diatas, peneliti tertarik melakukan penelitian dengan judul Pengaruh Edukasi Stunting Menggunakan Metode Booklet dan Audiovisual Terhadap Pengetahuan Ibu dengan Anak Stunting Di Desa Jekani Mondokan Sragen.

Penelitian ini menggunakan non equivalent control group design. Dengan menggunakan desain ini, kelompok eksperimen memiliki karakteristik yang sama, karena diambil secara purposive sampling. Dalam desain ini kedua kelompok terlebih dahulu diberi tes awal (pretest) dengan tes yang sama. Kemudian kelompok eksperimen diberi perlakuan khusus yaitu penyuluhan dengan menggunakan audiovisual dan booklet. Setelah diberikan perlakuan kedua di tes dengan tes yang sama sebagai tes akhir (postest) hasil kedua tes akhir dibandingkan, demikian juga antara hasil tes awal dengan tes akhir pada masing-masing kelompok. Sampel pada penelitian ini berjumlah $60 \mathrm{ibu}$ - ibu di desa Jekani yang memiliki anak stunting. Variabel bebas (independent variable) dalam penelitian ini adalah pemberian penyuluhan dengan media audiovisual dan pemberian penyuluhan dengan media booklet dan Variabel terikat (dependent variable) dalam penelitian ini adalah tingkat pengetahuan ibu dengan anak stunting. Penelitian ini menggunakan instrumen penelitian berupa kuesioner semua baik pengetahuan tentang stunting. Penelitian ini menggunakan uji parametrik, uji analisis dilakukan dengan paired t-test untuk membandingkan rata-rata pengetahuan dari dua kelompok, kemudian analisa indpenden $t$-test untuk mengetahui perbedaan nilai rata-rata antara satu kelompok dengan kelompok lain.

Uji Normalitas data dilakukan dengan menggunakan One Sample KolmogorovSmirnov dengan menggunakan sistem SPSS.

\section{METODE}


a) Kelompok Eksperimen ${ }^{1}$

Hasil uji normalitas tingkat pengetahuan ibu dengan anak stunting di Desa Jekani, Kecamatan Mondokan Sragen sebelum dilakukan edukasi dengan Media Audiovisual (Video) adalah 0,434 dan sesudah dilakukan edukasi dengan Media Audiovisual (Video) adalah 0,561. Maka dapat disimpulkan bahwa data berdistribusi normal karena data memiliki nilai $>0,05$.

b) Kelompok Eksperimen ${ }^{2}$
Hasil uji normalitas tingkat pengetahuan ibu dengan anak stunting di Desa Jekani, Kecamatan Mondokan Sragen sebelum dilakukan edukasi dengan Media Booklet adalah 0,221 dan sesudah dilakukan edukasi dengan Media Booklet adalah 0,565. Maka dapat disimpulkan bahwa data berdistribusi normal karena data memiliki nilai $>0,05$.

2. Paired Sample T-Test

a) Paired Sampel T-Test Kelompok Eksperimen $^{1}$

Tabel 2

Paired Sampel T-Test Kelompok Eksperimen ${ }^{1}$

\begin{tabular}{cccccc}
\hline Kelompok & $\mathrm{N}$ & $\begin{array}{c}\text { Pre-Post } \\
\text { Mean } \pm \text { SD }\end{array}$ & $\mathrm{T}$ & $\begin{array}{c}\text { Low- } \\
\text { upper }\end{array}$ & $\begin{array}{c}p- \\
\text { value }\end{array}$ \\
\hline Media & 30 & $27,903 \pm 17,126$ & 8,774 & 34,418 & 0,000 \\
Audiovisual & & & - & 21,389 \\
\end{tabular}

Tabel terserbut menunjukkan hasil uji paired $t$-test pada kelompok eksperimen ${ }^{1}$ dengan nilai $p$-value dapat disimpulkan bahwa ada perbedaan yang signifikan antara sebelum dan sesudah penyuluhan dengan Media Audiovisual ( $p$-value $<0,05)$. Hal ini dapat dilihat dari nilai mean \pm SD pada kelompok eksperimen ${ }^{1}$ yaitu pada hasil pretest dan posttest adalah $27,903 \pm 17,126$.

b) Paired Sampel T-Test Kelompok Eksperimen $^{2}$

Tabel 3

Paired Sampel T-Test Kelompok Eksperimen ${ }^{2}$

\begin{tabular}{lccccr}
\hline Kelompok & $\mathrm{N}$ & $\begin{array}{c}\text { Pre-Post } \\
\text { Mean } \pm \text { SD }\end{array}$ & $\mathrm{T}$ & $\begin{array}{c}\text { Low- } \\
\text { upper }\end{array}$ & $\begin{array}{c}\text { p- } \\
\text { value }\end{array}$ \\
\hline Media Booklet & 30 & $27,644 \pm 14,352$ & 10,550 & 33,003 & 0,000 \\
& & & - & 22,245 \\
\hline
\end{tabular}

Tabel tersebut menunjukkan hasil uji paired $t$-test pada kelompok eksperimen ${ }^{2}$ dengan nilai $p$-value dapat di simpulkan bahwa ada perbedaan yang signifikan antara sebelum dan sesudah dilakukannuya penyuluhan menggunakan Media Booklet ( $p$-value $<0,05)$.
Hal ini dapat dilihat dari nilai mean \pm SD pada kelompok eksperimen ${ }^{2}$ yaitu pada hasil pretest dan posttest adalah $27,644 \pm 14,352$.

c) Independent Sampel T-Test Kelompok Eksperimen $^{1}$ dan Eksperimen ${ }^{2}$

Tabel 4

Independent Sampel T-Test Kelompok Eksperimen ${ }^{1}$ dan Kelompok Eksperimen ${ }^{2}$

\begin{tabular}{cccccc}
\hline & $\begin{array}{c}\text { Beda } \\
\text { Mean }\end{array}$ & $\begin{array}{c}\text { Beda } \\
\mathrm{t}\end{array}$ & Lower & Upper & $\begin{array}{c}\mathrm{p}- \\
\text { value }\end{array}$ \\
\hline Selisih & 0,951 & & & & \\
& & 3,318 & 5,620 & & \\
& & 0,286 & & & \\
\hline
\end{tabular}

Berdasarkan hasil analisis uji Independent t-test pada tabel didapatkan nilai perbedaan rata-rata selisih pengetahuan pada kelompok eksperimen ${ }^{1}$ dan kelompok eksperimen $^{2}$ yaitu $0,951 \pm 3,318$. Hasil analisis tersebut juga menunjukkan p-value $<\alpha$ $(0,000<0,05)$, maka Ho ditolak dan Ha diterima yang artinya ada pengaruh penyuluhan dengan 
media Audiovisual dan booklet terhadap pengetahuan ibu dengan anak stunting.

\section{PEMBAHASAN}

Menurut hasil analisis data diketahui selisih ratarata antara responden yang dilakukan edukasi dengan media audiovisual dan edukasi dengan media booklet adalah $0,951 \pm 3,318$ dengan $p$ value $0,000<0,05$ maka Ho ditolak dan $\mathrm{Ha}$ diterima yang artinya ada perbedaan pengaruh . Menurut Daryanto (2011) dalam Kurniawati (2014) mengungkapkan bahwa daya serap manusia yang hanya mengandalkan indera penglihatan saja hanya berkisar $82 \%$. Pada media booklet, hanya memperoleh materi dengan mengandalkan indera penglihatan saja. Sesuai dengan teori Notoatmodjo (2013) menyatakan bahwa terdapat faktor yang mempengaruhi ketidakberhasilan suatu proses pemberian penyuluhan dilihat dari faktor booklet kurang menarik perhatian, gambar yang menyertai tema, warna tulisan yang kurang mencolok, bahasa yang digunakan kurang dapat dimengerti oleh sasaran, dan penyampaian materi yang monoton. Hasil penelitian Wijayanti (2014) juga menunjukkan ada perbedaan efek edukasi stunting menggunakan audiovisual dengan media booklet terhadap peningkatan pengetahuan ibu.

Penelitian ini membuktikan ada perbedaan pengaruh edukasi terhadap pengetahuan ibu dengan anak stunting dengan metode audiovisual dan booklet hal tersebut sejalan dengan penelitian Asri Masitha Arsyanti (2019) dengan judul Pengaruh Penyuluhan Media Audiovisual Dalam Pengetahuan Pencegahan Stunting pada Ibu Hamil di Desa Cibatok 2 Cibungbulang didapatkan hasil yaitu Edukasi Audio Visual dan simulasi terbukti meningkatkan perubahan pengetahuan pencegahan stunting dari $50 \%$ menjadi $78,6 \%$. penyuluhan tentang stunting menggunakan metode audio visual lebih berpengaruh terhadap tingkat pengetahuan ibu dengan anak stunting. Diperlukan perhatian lebih dalam masyarakat mengenai pendidikan tentang stunting, misalnya meningkatkan, kerjasama antara Kementerian
Pendidikan, Kementerian Kesehatan, dan kementerian terkait lainnya untuk bersinergi sehingga kegiatan penyuluhan mengenai stunting dapat dikembangkan untuk dapat menunjang pengetahuan ibu.

\section{SIMPULAN DAN SARAN \\ Simpulan}

Ada perbedaan pengaruh edukasi menggunakan metode audiovisual dan booklet terhadap pengetahuan ibu dengan anak stunting. Didapatkan nilai perbedaan rata-rata selisih pengetahuan pada kelompok eksperimen ${ }^{1}$ dan kelompok eksperimen ${ }^{2}$ yaitu $0,951 \pm 3,318$. Hasil analisis tersebut juga menunjukkan $p$-value $<\alpha$ $(0,000<0,05)$.

\section{Saran}

Diharapkan ibu lebih berpartisipasi aktif dalam pemanfaatan fasilitas dan pelayanan kesehatan yang ada baik di puskesmas maupun posyandu sehingga dapat menurunkan prevalensi stunting pada anak balita dan masalah kesehatan anak dapat selalu terpantau dan teratasi dengan baik.

\section{DAFTAR PUSTAKA}

Arsyati, A. M. (2019). Pengaruh Penyuluhan Media Audiovisual dalam Pengetahuan Pencegahan Stunting Pada Ibu Hamil di Desa Cibatok 2 Cibungbalang. Vol. 2 No. 3,182-190.

Kementrian Kesehatan RI. (2017). Buletin Stunting 2018. Jakarta: Kemenkes RI

Kurniawati (2014). Komunikasi Antar Pribadi : Konsep Dan Teori Dasar. Yogyakarta : Graha Ilmu

Mugianti Sri, A, dkk. (2018). Faktor Penyebab Anak Stunting Usia 25-60 Bulan. Malang: Kemenkes

Naila Fauziatin, (2019). Pengaruh Media Audio Visual Terhadap Tingkat Pengetahuan Dan Sikap Pada Ibu Hamil Tentang Pencegahan Stunting Di Desa Citra Rakyat .Jurnal Ilmiah Kebidanan Imelda. Vol. 6 No 1, Maret 2020

Natoatmodjo, S. (2013). Kesehatan Masyarakat Jakarta.Jakarta: Rineka Cipta. 